\title{
Spatially resolved diamond formation and metasomatism in the Kroonstad mantle (RSA)
}

\author{
MAYA G KOPYLOVA ${ }^{1}$, MARINA KARAEVANGELOU ${ }^{1}$ \\ AND PAUL LOUDON ${ }^{2}$ \\ ${ }^{1}$ University of British Columbia \\ ${ }^{2}$ DiamondCorp \\ Presenting Author: mkopylov@eos.ubc.ca
}

We studied diamond inclusions (DI) in the 133 Ma Lace kimberlite of the Kroonstad Group II kimberlite cluster (RSA, Kaapvaal craton) in order to constrain the diamond parageneses and collect data on the thermal state and thickness of the mantle beneath Kroonstad. Forty three Lace diamonds were classified as eclogitic (44\%, 19 samples), peridotitic (35\%, 15 samples) and websteritic ( $9 \%, 4$ samples). Nitrogen thermometry and various types of single crystal and traditional thermobarometry of DI enabled reconstruction of the petrological evolution of the Lace mantle that shed light on the distinct history and metasomatic events compared to the mantle beneath the adjacent Voorspoed kimberlite $7 \mathrm{~km} \mathrm{NE}$, as indicated by Voorspoed DI and macrocrysts. Peridotitic diamonds at Lace and Voorspoed may have formed in the Archean; eclogitic diamonds were added at 2$2.6 \mathrm{Ga}$, as suggested by the Hf model age of the Lace DI eclogitic zircon. A hot and spatially restricted event of metasomatism may have heated the Voorspoed mantle at $188 \pm$ $33 \mathrm{Ma}$ (based on the ${ }^{206} \mathrm{~Pb} /{ }^{238} \mathrm{U}$ age of the Lace DI zircon), giving birth to diamonds with very aggregated nitrogen and uncommon Si-rich pyroxenes exsolving into clinopyroxene, orthopyroxene and coesite. Isobaric thermal relaxation subsequently returned the mantle to the steady-state local geotherm of $39-38 \mathrm{~mW} / \mathrm{m}^{2}$ recorded in the Lace DIs and Voorspoed macrocrysts. The requirement of Lace DIs coming from the diamond stability field constrains the upper bound on the local geotherm at $39 \mathrm{~mW} / \mathrm{m}^{2}$. Samples from both Lace and Voorspoed pipes map the 210-220 km deep Kroonstad lithosphere that persisted from the Archean to the Cretaceous. Comparison of the diamond parageneses in the adjacent pipes of the Kroonstad cluster highlights the very local (ca. $10 \mathrm{~km})$ extent of the metasomatism and heating, as well as the variability of the mantle lithologies and diamond assemblages at the same spatial scale. This pattern has been observed in some occurrences of the neighbouring and contemporaneous kimberlites, for example pipes of the Chidliak kimberlite province on Baffin Island (North Atlantic Craton) and Muskox and Jericho pipes (Northern Slave craton). 